\title{
Construction project productivity assesment model and its implementation in Indonesia construction industry
}

\author{
Rintih Prastianing Atas Kasih ${ }^{1, *}$, and Tri Joko Wahyu Adi ${ }^{2, * *}$ \\ ${ }^{1}$ Master Student, Civil Engineering Department, 60111 Institut Teknologi Sepuluh Nopember Surabaya, Indonesia \\ ${ }^{2}$ Lecturer, Civil engineering Department, 60111 Institut Teknologi Sepuluh Nopember Surabaya, Indonesia
}

\begin{abstract}
The increase of global competition in the world of construction forced construction companies to increase their productivity. One of the most important parts of the construction project is productivity. It is absolutely necessary to have a thorough research on the construction project productivity (CPP), so that contractors know the productivity level of their projects. This assessment has an effect on increasing the productivity of a construction project until it achieves the highest level of the construction project productivity. The purpose of this study is to propose a construction project productivity assesment model. In this study, project productivity variables are obtained by conducting in-depth literature review and structured interview with construction experts. Pairwise comparison is used to determine the factor weight. The final assessment is represented in the form of a web spider graph. To validate the model, several building projects in Indonesia are used as a case study. The weight for the CPP assessment at the internal level was $73.8 \%$ at an external rate of $26.2 \%$. At the internal level, there are 2 categories namely: management category for $39.38 \%$ and human category for $34.42 \%$. CPP results in Indonesia are the highest in the category of human variable worker turnover and availability while the lowest is in the category of management inspection delays.
\end{abstract}

\section{Introduction}

Project management in the world of construction is very important. One of the most important parts of project management is productivity. In the highly competitive world of construction and the labor-intensive world of construction in Indonesia, high productivity performance can increase profits and produce competitive products. Otherwise it is created from efficient productivity such as expected quality [1].

High productivity becomes very important to achieve excellence in terms of cost, time and quality. Therefore, many actors of construction are developing. The actors of construction who cannot be used to increase productivity will face difficulties in competing in the construction world. So it is necessary to model the productive measurement of construction projects $[2,3]$.

Optimal productivity is not only with good management but is also from the various components involved in the process that increase at any time $[3,4]$. The productivity measurement model is instead of work that provides guidance or processes for the productivity process [5]. The purpose of this model is to measure current productivity and future improvement efforts. Models provide great information from very small

\footnotetext{
*email : rintih.kasih@gmail.com

**email : trijokowahyuadi@gmail.com
}

numbers and thus generally explain how to apply productivity improvements [6].

The purposes of the productivity assessment model used are: First, it is used to determine the position and to become the right source of information in applying productivity, because if it does not know the existing position it will not be able to determine the strategies to improve future productivity. Second, it is a frame work to prioritize actions to be addressed. Third, the productivity assessment model of construction project is a tool for assessment.

Much research has been done on productivity of project constrcutions, but in that case the focus only on the factors that affect construction productivity. Not much research has focused on modeling for the assessment of construction productivity. Meanwhile, the research on the development of efficient projects is especially contractors who take the biggest role as construction workers. So they can take measurements, and take strategic steps to improve productivity and optimize time, cost and quality [4,7,8].

The construction practitioners who cannot prepare to increase productivity will be abandoned because of constraints in terms of time, cost and quality of difficulties to compete. So it is very necessary to 
measure the construction work of the project. This study aims to develop models that are important for construction work based on two levels, namely internal and external.

This study has the following word limitations:

1. The research was conducted on 3 large contractors and 4 private contractors in Surabaya and Jakarta, Indonesia. This measurement is only for case study. This study does not compare (rank) with CPP, but only to apply the model. The model that can be used in this research can be implemented for all types of building construction projects.

2. Small contractors are not possible in this study because they may not have an optimal management system.

The advantages of this research are:

1. The advantage to develop science, which is a reference of similar research

2. Practical advantage, which can be a reference by practitioners to measure CPP (Productivity of construction projects) in building construction projects.

3. The CPP ranking model (Productivity of the construction project) in this study can be used as a self-assessment for the performance of a construction project.

4. The latest CPP model (Productivity of a construction project) which in this study can be a benchmark by working people and projects, they can understand their strengths and weaknesses.

5. The CPP rating model (Productivity of a construction project) can also be a corrective action to increase the productivity of their construction project.

Internal factors are any factors within the project. In general, they will simultaneously affect the construction project [7]. Among them are Human whose work identifies skills and operational experience impacts on the efficiency of labor productivity of construction [8], [9] as well as management-defined management as the application of processes, methods, knowledge, skills and experience to achieve the project objectives [10] and as the application of knowledge, skills, tools, and techniques in project activities to meet PMI project requirements [11].

External factors affecting productivity come from other factors beyond the control of the project. In general they will simultaneously affect the construction project so that in this case all activities undertaken on the construction project will be largely determined by the entire project environment that influences it [12].

Productivity is defined as the relationship between output in the form of goods and services with inputs in a typical production process expressed in ratios [13], [14], [15-24].

The Contractor is defined as the person or body that receives the job and conducts the work at the cost specified in accordance with the drawings of the plan and the rules and conditions set out [24].

Some definitions of the construction project are described below: The construction project is a set of work aimed at achieving the project objectives according to the requirements established at the beginning of the project such as quality, time and cost requirements ([21], [22 ], [25], [26], [27], [28]).

Productivity in a construction project is a comparison between the output of the project generated and the input given to a series of project activities. Productivity in construction projects is increased if output produced by a series of project activities is also increased when compared with before, while productivity decreases when there is a decrease in output produced when compared with before [31].

The productivity of a construction project is influenced by several categories of sources obtained. Productivity is classified into categories of management, labor / human and industry [1]; Internal, project and external categories [30]; Internal and external categories, [31]; primary and secondary categories [32]. At the national level, the construction industry in each country has a different application of its construction methods, the availability of resources, the Law with existing provision. The categories change over time. Therefore, to measure development productivity, we need to learn about productivity [33].

Description of the productivity level of the construction project is as follows: Level

1: Very unproductive; Level 2: Not Productive; Level 3: Self Productive; Level 4: Productive; Level 5: Very Productive.

\section{Method}

\subsection{Research methodology}

This research used case study on building construction project in Java as a research object. The determination of research variable was done by literature study in depth and validated by the experts. To assess CPP on existing construction projects, there were 15 variables at the internal level of management and Human categories. For the category of management there were 10 variables such as: Tool Availability, Availability of Materials, Construction Technology, Constructability Design, Adequacy of Planning \& Risk Management Process, Rework, Site Layout, Safety, Construction Project Management, and Inspection Delays. There were 5 categories of Human such as: Leadership, Labor Operating System, Teamwork, and Communication. In the external level there were 4 variables that were weighted: Change Orders, Partnership Interaction, Weather and Location. While the external level had 4 variables such as: Change Orders, Partnership Interaction, Weather and Location.

Weighted variables by pairwise comparison method are based on interviews with experts. There were 15 experts who became respondents for weighted with pairwise comparison method. Data analysis used average analysis and was represented in the form of a spider web. The model validation of the case used study 7 construction projects in Java. Questionnaires for the 
assessment of construction projects productivity in this assessment were carried out on 7 construction projects: project A (large state-owned contractor), project B (large state-owned contractor), Project C (large state-owned contractor), Project D (medium private contractor) Project E (Medium private contractor), F project (Medium private contractor), Project G (Medium private contractor). There are 4 respondents from each contractor to assess project productivity namely project manager, supervisory consultant, designer, and quantity surveyor.

\subsection{Research variables}

Variables were obtained from literature review and interviews with experts. The research variables are shown in Table 1.

Table 1. Research variables

\begin{tabular}{|c|c|c|}
\hline No & Variable & Description \\
\hline \multicolumn{3}{|c|}{ Category internal : Management variables [32-36] } \\
\hline M1 & $\begin{array}{l}\text { Tool } \\
\text { Availability }\end{array}$ & $\begin{array}{l}\text { the tools are always } \\
\text { available in the site so there } \\
\text { is no waiting time in } \\
\text { carrying out the work }\end{array}$ \\
\hline M2 & $\begin{array}{l}\text { Availability of } \\
\text { Materials }\end{array}$ & $\begin{array}{l}\text { There is always material } \\
\text { available in the site so there } \\
\text { is no waiting time }\end{array}$ \\
\hline M3 & $\begin{array}{l}\text { Construction } \\
\text { Technology }\end{array}$ & $\begin{array}{l}\text { Adequate construction } \\
\text { technology can support } \\
\text { faster and more efficient } \\
\text { implementation }\end{array}$ \\
\hline M4 & $\begin{array}{l}\text { Constructa } \\
\text { bility } \\
\text { Design }\end{array}$ & $\begin{array}{l}\text { Constructibility is very } \\
\text { supportive in efficient } \\
\text { execution and there are no } \\
\text { errors in the implementation } \\
\text { with good constructiveness }\end{array}$ \\
\hline M5 & $\begin{array}{l}\text { Adequacy of } \\
\text { planning \& Risk } \\
\text { management } \\
\text { process }\end{array}$ & $\begin{array}{l}\text { Planning and risk are the } \\
\text { important factors to } \\
\text { maximize productivity. }\end{array}$ \\
\hline M6 & Rework & $\begin{array}{l}\text { Lack of Rework arising } \\
\text { from work performed. }\end{array}$ \\
\hline M7 & Site Layout & $\begin{array}{l}\text { Optimal layout } \\
\text { arrangement with high } \\
\text { productivity minimal } \\
\text { movement. }\end{array}$ \\
\hline M8 & Safety & $\begin{array}{l}\text { Any work that refers to } \\
\text { safety resulting in minimal } \\
\text { accidents }\end{array}$ \\
\hline M9 & $\begin{array}{l}\text { Construction } \\
\text { Project } \\
\text { Management }\end{array}$ & $\begin{array}{l}\text { system project } \\
\text { management that is arranged } \\
\text { effectively by covering all } \\
\text { conditions in the project. }\end{array}$ \\
\hline
\end{tabular}

\begin{tabular}{|c|c|c|}
\hline M10 & $\begin{array}{l}\text { Inspection } \\
\text { Delays }\end{array}$ & $\begin{array}{l}\text { There is always a } \\
\text { supervisor in the } \\
\text { implementation so that it } \\
\text { runs smoothly. }\end{array}$ \\
\hline \multicolumn{3}{|c|}{$\begin{array}{c}\text { Category internal: Human variables } \\
{[27],[31],[32],[34],[35],[36],}\end{array}$} \\
\hline $\mathrm{H} 1$ & Leadership & $\begin{array}{l}\text { relates to the } \\
\text { performance of leaders } \\
\text { in solving existing } \\
\text { problems }\end{array}$ \\
\hline $\mathrm{H} 2$ & $\begin{array}{l}\text { Labour operating } \\
\text { system }\end{array}$ & $\begin{array}{l}\text { Relates to the skills and } \\
\text { work skills in operating } \\
\text { something in doing the job }\end{array}$ \\
\hline H3 & Teamwork & $\begin{array}{l}\text { Cooperation created to } \\
\text { optimize a job }\end{array}$ \\
\hline $\mathrm{H} 4$ & Communication & $\begin{array}{l}\text { Effective } \\
\text { communication so that } \\
\text { all instructions and } \\
\text { understanding are } \\
\text { delivered properly and } \\
\text { work is done optimally }\end{array}$ \\
\hline H5 & $\begin{array}{l}\text { Worker } \\
\text { Turnover\& } \\
\text { Availability }\end{array}$ & $\begin{array}{l}\text { Relates to the } \\
\text { availability of human } \\
\text { resources and in } \\
\text { accordance with the work } \\
\text { capacity so there is no } \\
\text { waiting time }\end{array}$ \\
\hline \multicolumn{3}{|c|}{ Category External ([27-32],[34-33]) } \\
\hline $\mathrm{E} 1$ & Change Orders & $\begin{array}{l}\text { Changes, additions and job } \\
\text { reductions have a significant } \\
\text { impact }\end{array}$ \\
\hline E2 & $\begin{array}{l}\text { Partnership } \\
\text { interaction }\end{array}$ & $\begin{array}{l}\text { Establish good } \\
\text { relationships with all } \\
\text { project-related organizations }\end{array}$ \\
\hline E3 & Weather & $\begin{array}{l}\text { Weather is very } \\
\text { influential in the timing } \\
\text { of implementation and } \\
\text { change the method of } \\
\text { work and accidents } \\
\text { caused significantly }\end{array}$ \\
\hline E4 & Location & $\begin{array}{l}\text { Location is very } \\
\text { influential in the } \\
\text { arrangement of site lay } \\
\text { out and procurement. }\end{array}$ \\
\hline
\end{tabular}

\subsection{Construction project productivity (CPP) Model}

Construction Project Productivity Model is shown in Figure 1 with literature review results and expert interviews.

\section{Result and discussion}

After weighing the Pairwise Comparison Method, the CPP diagram for weighting could be seen in Figure 2. 
This showed that the main level weighting for CPP assessment at internal level was $73.8 \%$ and at external level was $26.2 \%$, so the weighting for internal level was higher than the external level. Internal level for category management was $39,38 \%$ and human was $34,42 \%$.

After the validity and reliability of the data (questionnaire for productivity assessment at the internal and external levels of the project) was done and then followed by data processing.

Based on description of CPP productivity assessment [34] where there are a total of 5 levels, it can be concluded that project A (Productivity value $=3.21$ ) is between level 3 and 4 which is more likely to level 3 . Level 3 means: standardization has been used in the project and a measurement process is conducted to evaluate the effectiveness of the project.

The following is the result of calculation of project A (BUMN Project), where the mean value was obtained from the average results for input and input questionnaires then the average output / input while the weighting value was from the results pairwise comparison. Assessment for the internal level of management categories in Table 2 and Table 3 , the productivity level was 2.66 (from scale 5). The representation of spider web could be seen in Figure 2.

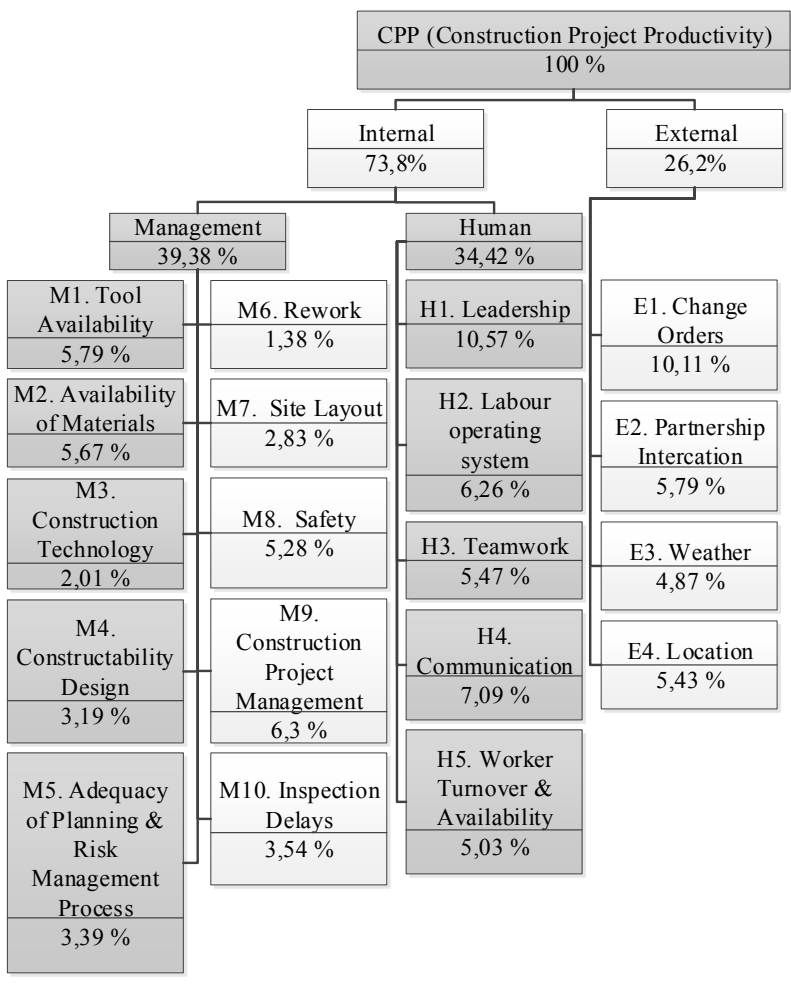

Figure 1. Model description and weight Costruction Project Productivity (CPP)

Table 2. Project's productivity value for the internal level of the M1-M6 management category

\begin{tabular}{|c|c|c|c|c|c|c|}
\hline \multicolumn{7}{|c|}{$\begin{array}{c}\text { Score Results for Internal Level Productivity: } \\
\text { Management Variable (Project A) }\end{array}$} \\
\hline & M1 & M2 & M3 & M4 & M5 & M6 \\
\hline Mean (M) & 2,89 & 2,91 & 2,56 & 2,67 & 2,13 & $\begin{array}{c}1,9 \\
7\end{array}$ \\
\hline $\begin{array}{c}\text { Weightin } \\
\text { g (W) }\end{array}$ & 0,15 & 0,14 & 0,05 & 0,08 & 0,09 & $\begin{array}{c}0,0 \\
4\end{array}$ \\
\hline M x W & 0,42 & 0,42 & 0,13 & 0,22 & 0,18 & $\begin{array}{c}0,0 \\
7\end{array}$ \\
\hline
\end{tabular}

The assessment for the internal level of the human category was showed in Table 4 , with a productivity value of 3.21 (of scale 5), while the spider web representation can be seen in Figure 3.

The productivity rating for the external level was showed in Table 5, with a 3.03 productivity value (from scale 5) including productivity which is self productive with the spider web representation shown in Figure 4.

Table 3. Project score for internal level management category M7-M10

\begin{tabular}{|c|c|c|c|c|c|}
\hline \multicolumn{5}{|c|}{$\begin{array}{c}\text { Score Results for Internal Level Productivity: } \\
\text { Management Variable (Project A) }\end{array}$} & \multirow[t]{3}{*}{$\sum$} \\
\hline & M7 & M8 & M9 & M10 & \\
\hline Mean (M) & $\begin{array}{c}2,6 \\
7\end{array}$ & $\begin{array}{c}2,5 \\
4\end{array}$ & $\begin{array}{c}2,6 \\
9\end{array}$ & 2,87 & \\
\hline $\begin{array}{l}\text { Weighting } \\
\text { (W) }\end{array}$ & $\begin{array}{c}0,0 \\
7\end{array}$ & $\begin{array}{c}0,1 \\
3\end{array}$ & $\begin{array}{c}0,1 \\
6\end{array}$ & 0,09 & 1,00 \\
\hline $\mathrm{MxW}$ & $\begin{array}{c}0,1 \\
9\end{array}$ & $\begin{array}{c}0,3 \\
4\end{array}$ & $\begin{array}{c}0,4 \\
3\end{array}$ & 0,26 & 2,66 \\
\hline & ory & $\begin{array}{l}\text { Inagen } \\
-\mathrm{Me} \\
{ }_{4}^{\mathrm{M} 1}\end{array}$ & $\begin{array}{l}\text { at (Pr } \\
\text { M) }\end{array}$ & & \\
\hline
\end{tabular}

Figure 2. Spider web project A for internal level management category

Table 4. Poject's productivity score for the internal level of the human category

\begin{tabular}{|c|c|c|c|c|c|c|}
\hline \multicolumn{6}{|c|}{$\begin{array}{c}\text { Score Result for Internal Level Productivity: } \\
\text { Human Variable (Project A) }\end{array}$} & \multirow[t]{3}{*}{$\Sigma$} \\
\hline & H1 & $\mathrm{H} 2$ & $\mathrm{H} 3$ & $\mathrm{H} 4$ & H5 & \\
\hline $\begin{array}{l}\text { Mean } \\
\text { (M) }\end{array}$ & 3,21 & 2,87 & 2,93 & 3,53 & 3,47 & \\
\hline $\begin{array}{c}\text { Weightin } \\
\mathrm{g}(\mathrm{W})\end{array}$ & 0,31 & 0,18 & 0,16 & 0,21 & 0,15 & 1,00 \\
\hline $\mathrm{MxW}$ & 0,99 & 0,52 & 0,47 & 0,73 & 0,51 & 3,21 \\
\hline
\end{tabular}

CPP project A where the results of the score obtained from the average value of each category with productivity value of 3.21 (from scale 5) entered into the 
category productively where the lowest variable value is the variable adequacy planning and risk management and process so it needs to be improved in risk and contingency planning is shown in Table 6 and the web spider representation can be seen in Figure 5.

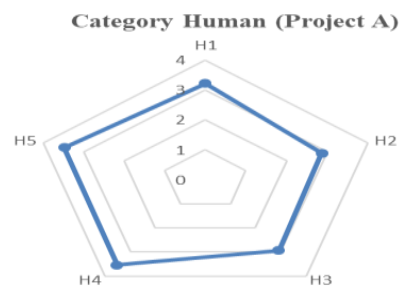

Figure 3. Spider web project A internal level of human category

Table 5. Productivity score A project for external level

\begin{tabular}{|c|c|c|c|c|c|}
\hline \multicolumn{5}{|c|}{$\begin{array}{l}\text { Score Results for Eternal Level Productivity } \\
\text { (Project A) }\end{array}$} & \multirow[t]{3}{*}{$\Sigma$} \\
\hline & E1 & E2 & E3 & $\mathrm{E} 4$ & \\
\hline Mean (M) & 2,77 & 3,23 & 3,33 & 3,03 & \\
\hline Weighting (W) & 0,38 & 0,22 & 0,18 & 0,20 & 1,00 \\
\hline $\mathrm{MxW}$ & 1,06 & 0,71 & 0,61 & 0,63 & 3,03 \\
\hline
\end{tabular}

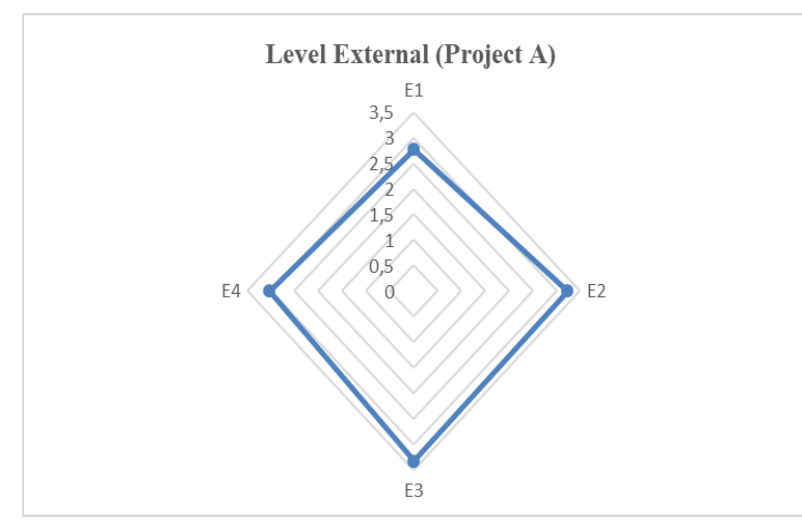

Figure 4. Spider web project A for external level

Table 6. Assessment of CPP for project A

\begin{tabular}{|c|c|c|c|c|}
\hline \multirow[t]{2}{*}{ Project A } & \multicolumn{2}{|c|}{ Internal } & \multirow{2}{*}{$\begin{array}{c}\text { Externa } \\
1\end{array}$} & \multirow[t]{3}{*}{$\Sigma$} \\
\hline & $\begin{array}{c}\text { Managemen } \\
\mathrm{t}\end{array}$ & $\begin{array}{c}\text { Huma } \\
n\end{array}$ & & \\
\hline Score (S) & 3,33 & 3,21 & 2,90 & \\
\hline $\begin{array}{c}\text { Weightin } \\
\text { g (W) }\end{array}$ & 0,39 & 0,34 & 0,26 & 1,00 \\
\hline $\mathrm{S} \times \mathrm{W}$ & 1,36 & 1,10 & 0,79 & 3,21 \\
\hline
\end{tabular}

The productivity appraisal could be seen from also in terms of time in Table 7, in terms of cost in Table 8 and in terms of quality in Table 9. From the aspect of time, cost and quality represented to the web spider is shown in Figure 6.

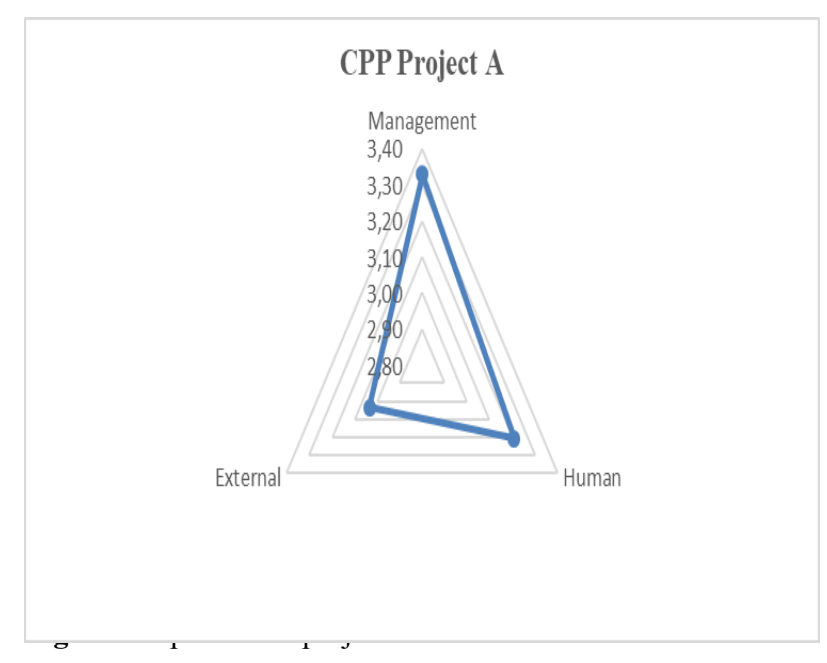

Table 7. Assessment of Project A CPP in terms of Time

\begin{tabular}{|c|c|c|c|c|}
\hline Project A & \multicolumn{2}{|c|}{ Internal } & External & $\sum$ \\
\cline { 2 - 3 } & Management & Human & & \\
\hline Score (S) & 3,2 & 3,08 & 2,90 & \\
\hline $\begin{array}{c}\text { Weighting } \\
\text { (W) }\end{array}$ & 0,39 & 0,34 & 0,26 & 1,00 \\
\hline S x W & 1,26 & 1,06 & 0,76 & 3,08 \\
\hline
\end{tabular}

Table 8. CPP Assessment of Project A in terms of Cost

\begin{tabular}{|c|c|c|c|c|}
\hline Project A & \multicolumn{2}{|c|}{ Internal } & External & $\sum$ \\
\cline { 2 - 4 } & Management & Human & & \\
\hline Score (S) & 3,40 & 3,28 & 3,10274 & \\
\hline $\begin{array}{c}\text { Weighting } \\
\text { (W) }\end{array}$ & 0,39 & 0,34 & 0,26 & 1,00 \\
\hline S x W & 1,34 & 1,13 & 0,81 & 3,28 \\
\hline
\end{tabular}

Table 9. CPP Assessment of Project A in Quality

\begin{tabular}{|c|c|c|c|c|}
\hline Project A & \multicolumn{2}{|c|}{ Internal } & External & $\sum$ \\
\cline { 2 - 4 } & Management & Human & & \\
\hline Score (S) & 3,10 & 2,98 & 2,80244 & \\
\hline $\begin{array}{c}\text { Weighting } \\
\text { (W) }\end{array}$ & 0,39 & 0,34 & 0,26 & 1,00 \\
\hline S x W & 1,22 & 1,02 & 0,73 & 2,98 \\
\hline
\end{tabular}




\section{PPC (Time, Cost and Quality) Project A}

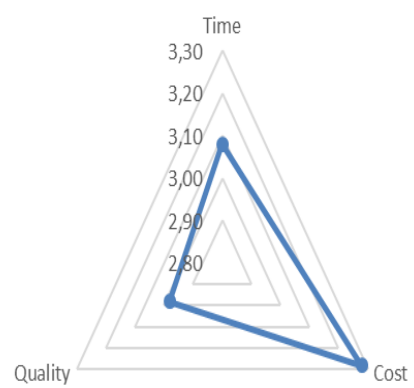

Figure 6. Spider web project A of time, cost \& quality

Here are the result calculations of 7 projects. Where Project A (large/BUMN contractor), Project B (large/BUMN contractor), Project C (large/BUMN contractor), Project D (Private contractor), Project E (Private contractor), Project F (Private contractor), Project G (Private contractor). Assessment for the internal levels of management categories in Table 10 and Table 11, with calculation the same as Table 2. The productivity level was 3.10 (from scale 5) including a self productive level. The representation of web spider could be seen in Figure 8 .

Table 10. The productivity values of $A$ to $G$ projects for internal levels of the M1-M6 management category

Score for Internal Productivity: Management Variable (Project A, B, C, D, E, F, G)

\begin{tabular}{|c|c|c|c|c|c|c|}
\hline & M1 & M2 & M3 & M4 & M5 & M6 \\
\hline Project A & 3,34 & 3,67 & 2,91 & 2,97 & 3,23 & 3,17 \\
\hline Project B & 3,13 & 3,27 & 3,73 & 3,32 & 2,93 & 2,87 \\
\hline Project C & 3,42 & 3,97 & 3,63 & 3,27 & 3,07 & 3,19 \\
\hline Project D & 2,92 & 3,36 & 3,15 & 3,27 & 3,56 & 3,64 \\
\hline Project E & 2,89 & 2,91 & 2,56 & 2,67 & 2,13 & 1,97 \\
\hline Project F & 2,17 & 2,35 & 2,69 & 2,93 & 2,87 & 3,03 \\
\hline Project G & 2,98 & 2,78 & 2,69 & 2,78 & 3,08 & 3,17 \\
\hline & M1 & M2 & M3 & M4 & M5 & M6 \\
\hline \begin{tabular}{c} 
Mean (M) \\
\hline $\begin{array}{c}\text { Weighting } \\
\text { (W) }\end{array}$
\end{tabular} & 0,15 & 0,14 & 0,05 & 0,08 & 0,09 & 0,04 \\
\hline M x W & 0,44 & 0,46 & 0,16 & 0,25 & 0,26 & 0,11 \\
\hline
\end{tabular}

Table 11. Project's score A-G for internal level management category M6-M10

\begin{tabular}{|c|c|c|c|c|c|}
\hline \multicolumn{5}{|c|}{$\begin{array}{c}\text { Score for Internal Level Productivity: } \\
\text { Management Variable (Project A, B, C, D, } \\
\text { E, F, G) }\end{array}$} & \multirow[t]{2}{*}{$\sum$} \\
\hline & M7 & M8 & M9 & M10 & \\
\hline Project A & 3,32 & 3,13 & 3,27 & 3,9 & \\
\hline Project B & 3,42 & 3,34 & 3,17 & 3,27 & \\
\hline Project C & 3,52 & 3,43 & 3,57 & 3,03 & \\
\hline Project D & 3,43 & 3,82 & 3,94 & 3,06 & \\
\hline Project E & 2,67 & 2,54 & 2,69 & 2,87 & \\
\hline Project F & 3,13 & 2,87 & 2,97 & 2,68 & \\
\hline \multirow[t]{2}{*}{ Project $\mathrm{G}$} & 2,65 & 2,98 & 2,88 & 2,43 & \\
\hline & M7 & M8 & M9 & M10 & \\
\hline Mean (M) & 3,16 & 3,16 & 3,21 & 3,03 & \\
\hline $\begin{array}{l}\text { Weighting } \\
\text { (W) }\end{array}$ & 0,07 & 0,13 & 0,16 & 0,09 & 1,00 \\
\hline $\mathrm{MxW}$ & 0,23 & 0,42 & 0,51 & 0,27 & 3,10 \\
\hline
\end{tabular}

Assessment for the internal level of the human category was shown in Table 12 with calculations such as Table 2, with productivity values of 2.89 (from scale 5 ) entering into self productive levels, while the spider web representation could be seen in Figure 8.

The productivity assessment for the external level is shown in Table 13 with a calculation the same as Table 2 , with a productivity value of 2.88 (from scale 5) entering into self productive levels with the spider web repsentation showed in Figure 9.

Projection of construction project (CPP) productivity in some construction projects in Indonesia with productivity value of 3,21 (from scale 5) was showed in Table 14 where the lowest is in the leadership variable (H1) so that it needs to be improved on competence, training and expertise with calculations such as Table 14 and spider web representation which could be seen in Figure 10.

The productivity appraisal could also be seen in terms of time from Table 15, with calculation the same as Table 6.

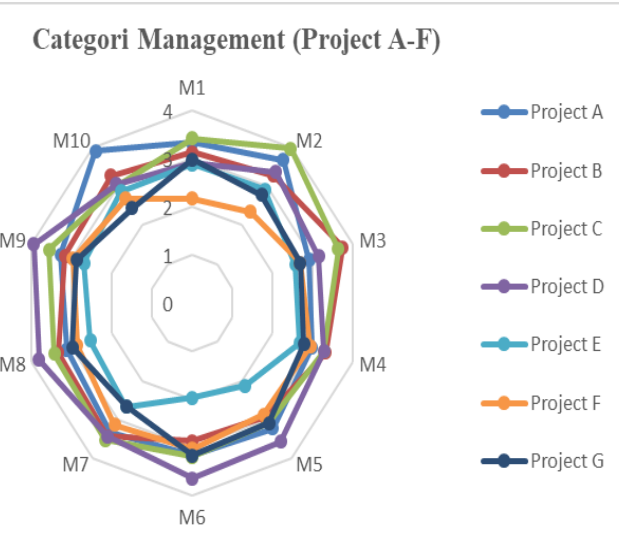

Figure 7. Spider web project A-G internal level management category 
Table 12. Productivity's score project A-G for internal level of human

\begin{tabular}{|c|c|c|c|c|c|c|}
\hline \multicolumn{6}{|c|}{$\begin{array}{l}\text { Score for Internal Level Productivity: Human } \\
\text { Variable (Project A, B, C, D, E, F, G) }\end{array}$} & \multirow[t]{11}{*}{$\sum$} \\
\hline & $\mathrm{H} 1$ & $\mathrm{H} 2$ & $\mathrm{H} 3$ & $\mathrm{H} 4$ & H5 & \\
\hline Project A & 3,21 & 2,87 & 2,93 & 3,53 & 3,47 & \\
\hline Project B & 3,34 & 3,13 & 3,27 & 2,89 & 3,95 & \\
\hline Project C & 3,28 & 3,19 & 2,98 & 3,87 & 3,69 & \\
\hline Project D & 2,98 & 3,07 & 3,04 & 3,15 & 3,06 & \\
\hline Project E & 2,21 & 2,57 & 2,97 & 3,15 & 2,8 & \\
\hline Project F & 1,9 & 1,84 & 2,47 & 2,86 & 3,01 & \\
\hline \multirow[t]{2}{*}{ Project G } & 1,72 & 1,92 & 2,57 & 2,86 & 2,92 & \\
\hline & H1 & $\mathrm{H} 2$ & H3 & $\mathrm{H} 4$ & H5 & \\
\hline Mean (M) & 2,66 & 2,66 & 2,89 & 3,19 & 3,27 & \\
\hline $\begin{array}{l}\text { Weighting } \\
\text { (W) }\end{array}$ & 0,31 & 0,18 & 0,16 & 0,21 & 0,15 & 1,00 \\
\hline$M \times W$ & 0,82 & 0,48 & 0,46 & 0,66 & 0,48 & 2,89 \\
\hline
\end{tabular}

The productivity assessment for the external level is shown in Table 13 with a calculation the same with Table 2, with a productivity value of 2.88 (from scale 5) entering into self productive levels ) with the spider web repsentation shown in Figure 9.

Projection of construction project (CPP) productivity in some construction projects in Indonesia with productivity value 3,21 (from scale 5) was showed in Table 14 where the lowest is in the leadership variable (H1) so that it needs to be improved on competence, training and expertise with calculations such as Table 14 and spider web representation could be seen in Figure 10.

The productivity appraisal could be seen from also in terms of time shown in Table 15, with calculation the same as Table 6.

The productivity assessment could also be seen in term of time from Table .15 with the calculation the same as Table 6. From the aspect of time, cost and quality represented to the web spider is showed in Figure 11.

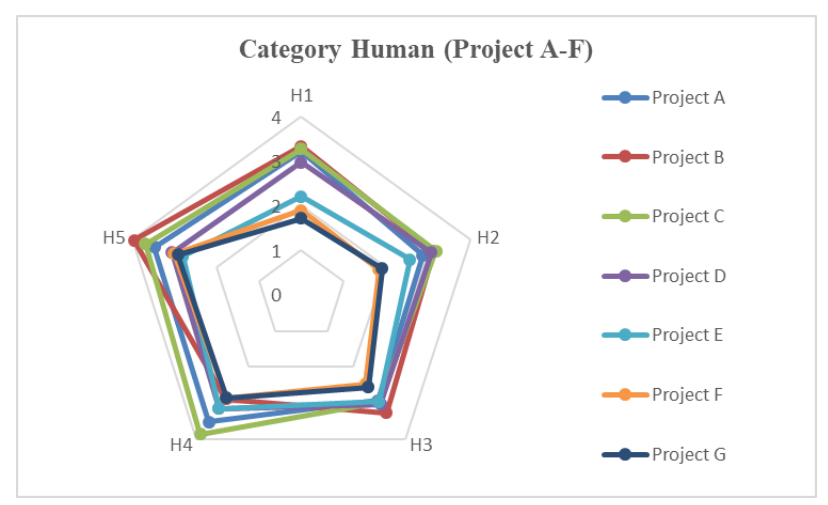

Figure 8. Spider web project A-G internal level human
Table 13. Productivity's score project A-G for eksternal level

\begin{tabular}{|c|c|c|c|c|c|}
\hline \multicolumn{5}{|c|}{$\begin{array}{l}\text { Score for Eksternal Level Productivity } \\
\text { (Project A, B, C, D, E, F, G) }\end{array}$} & \multirow[t]{11}{*}{$\sum$} \\
\hline & E1 & E2 & E3 & E4 & \\
\hline Project A & 2,77 & 3,23 & 3,33 & 3,03 & \\
\hline Project B & 2,93 & 2,73 & 3,12 & 3,69 & \\
\hline Project C & 2,94 & 2,87 & 2,93 & 3,19 & \\
\hline Project D & 3,15 & 3,23 & 3,36 & 3,14 & \\
\hline Project E & 2,19 & 2,8 & 2,76 & 2,72 & \\
\hline Project $\mathrm{F}$ & 2,34 & 2,62 & 2,89 & 2,71 & \\
\hline \multirow[t]{2}{*}{ Project G } & 2,5 & 2,71 & 2,91 & 3,09 & \\
\hline & E1 & E2 & E3 & E4 & \\
\hline Mean (M) & 2,69 & 2,88 & 3,04 & 3,08 & \\
\hline $\begin{array}{l}\text { Weighting } \\
\text { (W) }\end{array}$ & 0,39 & 0,22 & 0,19 & 0,21 & 1,00 \\
\hline$M \times W$ & 1,04 & 0,64 & 0,57 & 0,64 & 2,88 \\
\hline
\end{tabular}

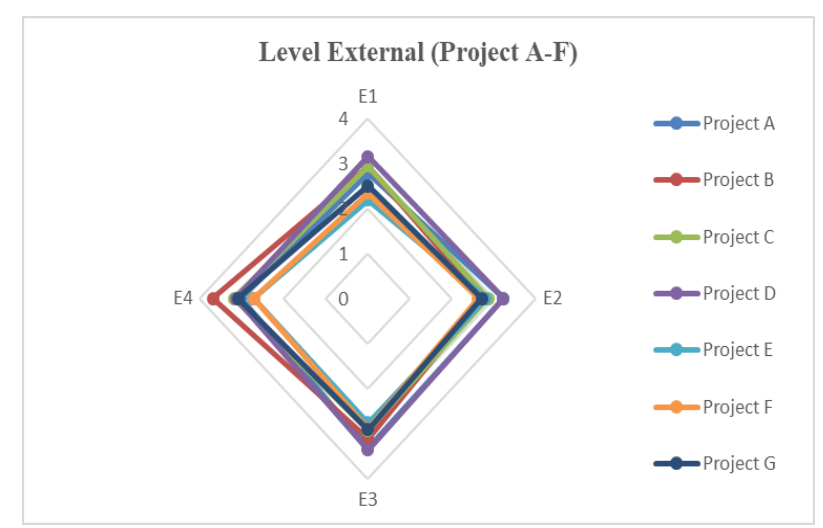

Figure 9 Spider web project A- G for external level

Table 14. Assessment CPP for A-G project

\begin{tabular}{|c|c|c|c|}
\hline \multirow{2}{*}{$\begin{array}{c}\text { Project's } \\
\text { Name }\end{array}$} & \multicolumn{2}{|c|}{ Internal } & External \\
\cline { 2 - 4 } & Management & Human & \\
\hline Project A & 3,33 & 3,21 & 3,03 \\
\hline Project B & 3,23 & 3,28 & 3,08 \\
\hline Project C & 3,45 & 3,39 & 2,97 \\
\hline Project D & 3,43 & 3,20 & 2,54 \\
\hline Project E & 2,66 & 2,67 & 2,54 \\
\hline Project F & 2,71 & 2,33 & 2,58 \\
\hline Project G & 2,84 & 2,30 & 2,74 \\
\hline
\end{tabular}


Table 16 .CPP assessement project from A-G

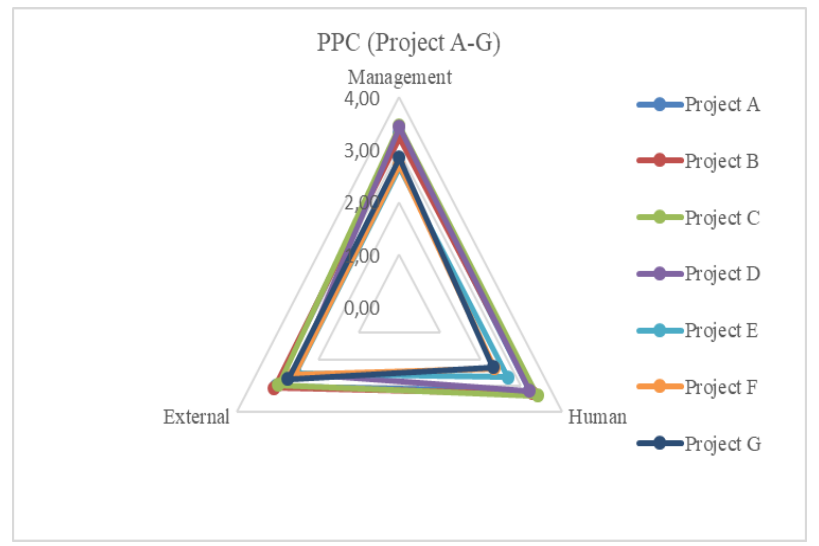

Figure 10. Spider Web CPP assessement for A-G project

Table 15. CPP assessement project A-G from time, cost and quality

\begin{tabular}{|c|c|c|c|}
\hline Project's Name & Time & Cost & Quality \\
\hline Project A & 3,08 & 3,28 & 2,98 \\
\hline Project B & 3,40 & 3,28 & 2,98 \\
\hline Project C & 3,47 & 3,38 & 3,08 \\
\hline Project D & 2,68 & 3,19 & 2,89 \\
\hline Project E & 2,76 & 2,71 & 2,41 \\
\hline Project F & 2,67 & 2,62 & 2,32 \\
\hline Project G & 2,78 & 2,70 & 2,40 \\
\hline
\end{tabular}

PPC (Time, Cost, Quality) Project A,B,C,D,E,F,G

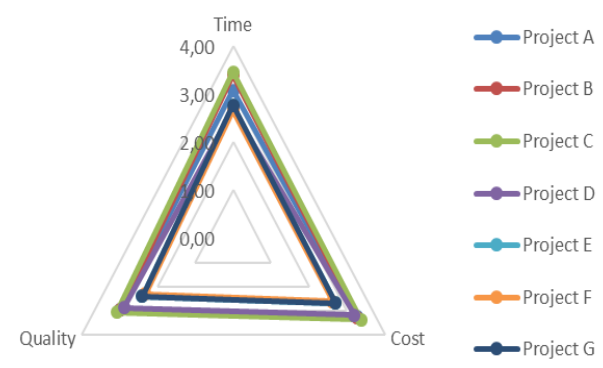

Figure 11 Spider web project A-G from time, cost and quality

Overall project productivity of 2.97 at level 3 means: standardization has been used in the project and a measurement process to evaluate the effectiveness of the project. The calculation Table was showed in Table 16 and the representation of spider web could be seen in Figure 12.

\begin{tabular}{|c|c|c|c|c|}
\hline $\begin{array}{c}\text { Project A, } \\
\text { B, C, D, } \\
\text { E, F, G }\end{array}$ & \multicolumn{2}{|c|}{ Internal } & External & $\sum$ \\
\cline { 2 - 4 } & Management & Human & & \\
\hline Score (S) & 3,10 & 2,89 & 2,88 & \\
\hline $\begin{array}{c}\text { Weighting } \\
\text { (W) }\end{array}$ & 0,39 & 0,34 & 0,26 & 1,00 \\
\hline S x W & 1,22 & 1,00 & 0,76 & 2,97 \\
\hline
\end{tabular}

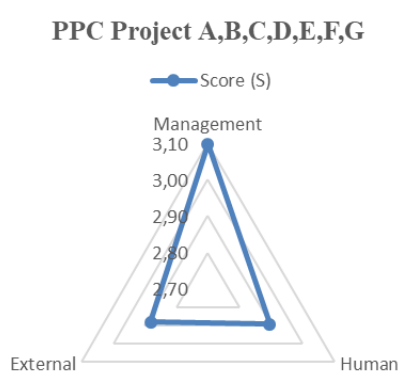

Figure 12. Spider web project A-G

The next calculation was productivity assessment with project grouping done by BUMN and private contractors where projects $\mathrm{A}, \mathrm{B}, \mathrm{C}$ were projects undertaken by BUMN contractors while projects $\mathrm{C}, \mathrm{D}$, $\mathrm{E}, \mathrm{F}, \mathrm{G}$ are projects by private contractors. The assessment for the internal level of the scoring management category for the BUMN project was 3.34 (from scale 5), while the score for private project was 2.91. The representation of spider web could be seen in Figure 13.

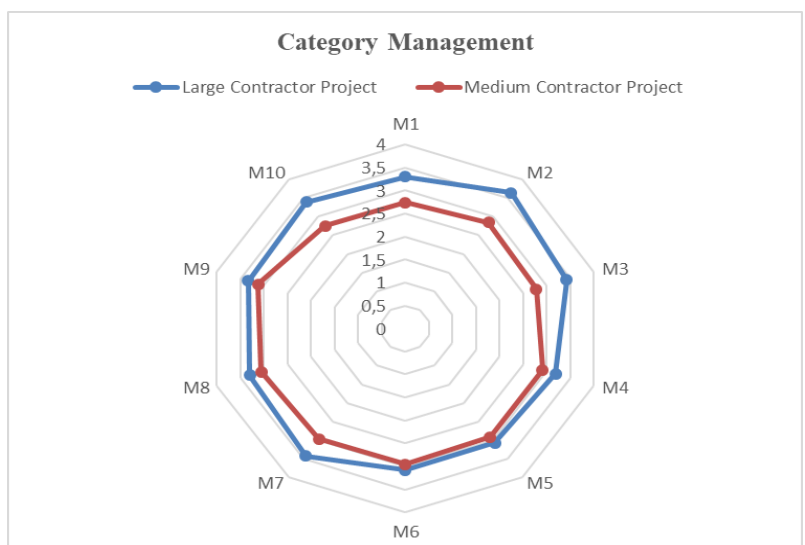

Figure 13. Spider web project of BUMN and Private internal level management category

Assessment for the internal level of the human category, the score for the productivity project was 3.3 (from scale 5) while the score for the private project was 2.59. The representation of spider web could be seen in Figure 14. 


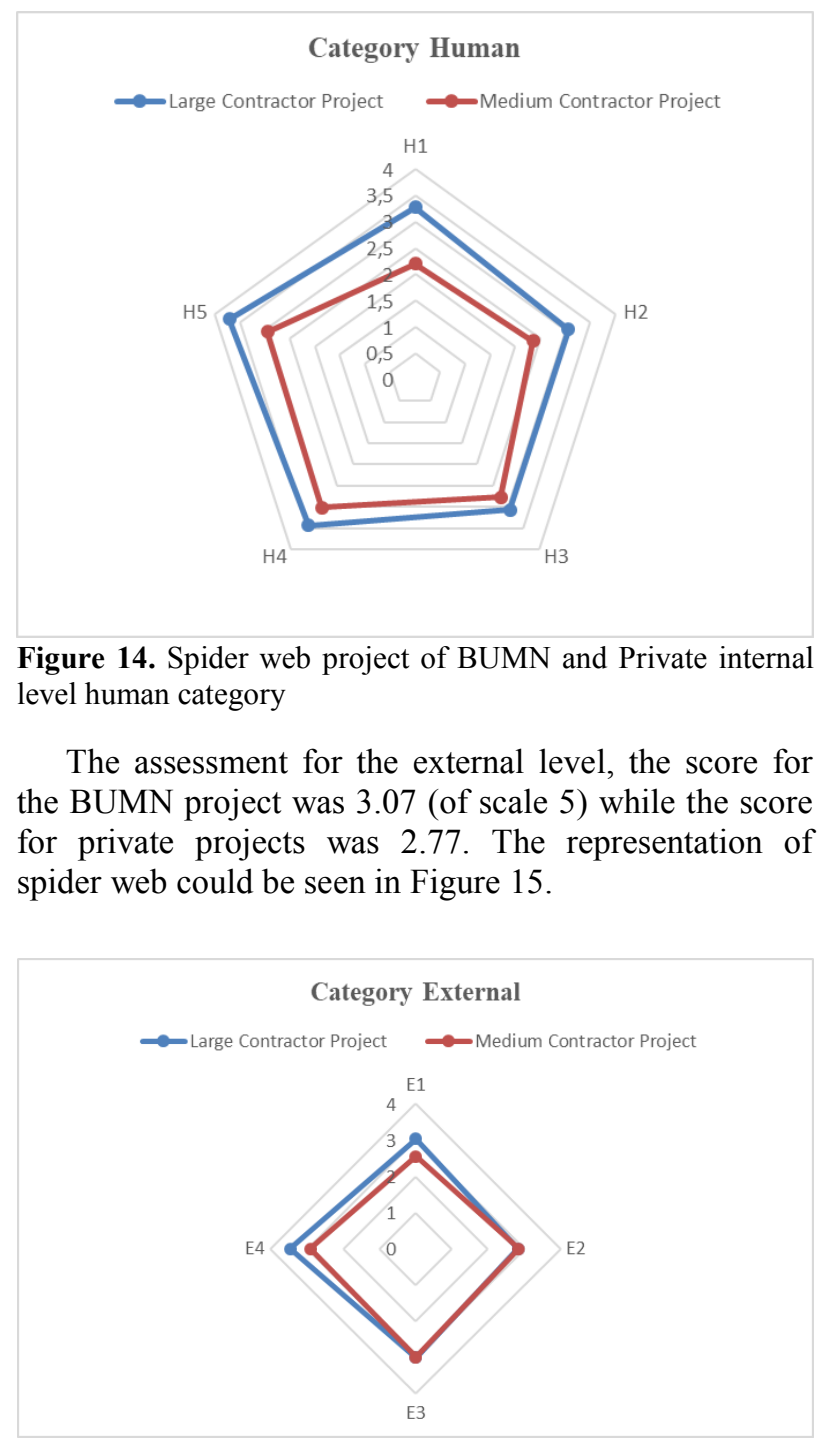

Figure 15. Spider web project BUMN and Private for external level

Construction project productivity projection (CPP) with grouping was done by BUMN and Private contractors, where the productivity value for the project undertaken by the BUMN contractor was 3.26 (of scale 5) and the project undertaken by private contractor was 2.77 (from scale 5) and the repsentation spider web could be seen in Figure 16.

The productivity appraisal could also be seen in terms of time from Table17. From the aspect of time, cost and quality represented to the web spider showed in Figure 17.

Overall project productivity of the BUMN contractor was 3.03 at level 4 means: standardization has been used in the project and also a measurement process to evaluate the effectiveness of the project while the productivity of the project undertaken by Private contractors was 2.97 at level 3 at position level of self productivity which could improve productivity.
Table 17. CPP assessment time, cost, and quality

\begin{tabular}{|l|c|c|c|}
\hline Productivity Project & Time & Cost & Quality \\
\hline $\begin{array}{l}\text { large contractor } \\
\text { project }\end{array}$ & 3,05 & 3,33 & 3,03 \\
\hline $\begin{array}{l}\text { medium contractor } \\
\text { project }\end{array}$ & 2,45 & 2,77 & 2,47 \\
\hline
\end{tabular}

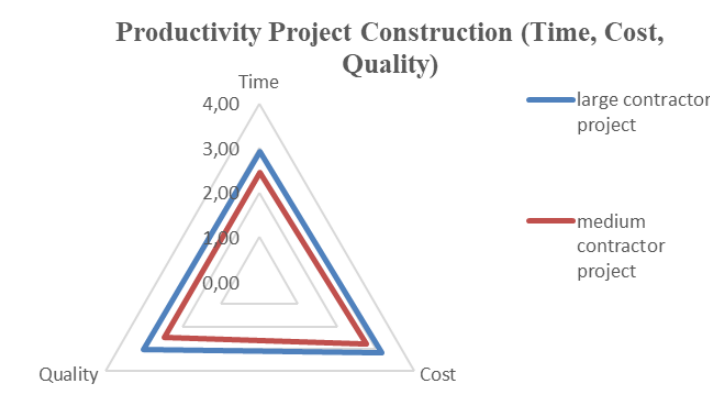

Figure 16. Spider web project BUMN and Private

Table 18. CPP assessment

\begin{tabular}{|l|c|c|c|}
\hline & Management & Human & External \\
\hline $\begin{array}{l}\text { large contractor } \\
\text { project }\end{array}$ & 3,13 & 3,17 & 2,96 \\
\hline $\begin{array}{l}\text { medium } \\
\text { contractor } \\
\text { project }\end{array}$ & 2,91 & 2,59 & 2,77 \\
\hline
\end{tabular}

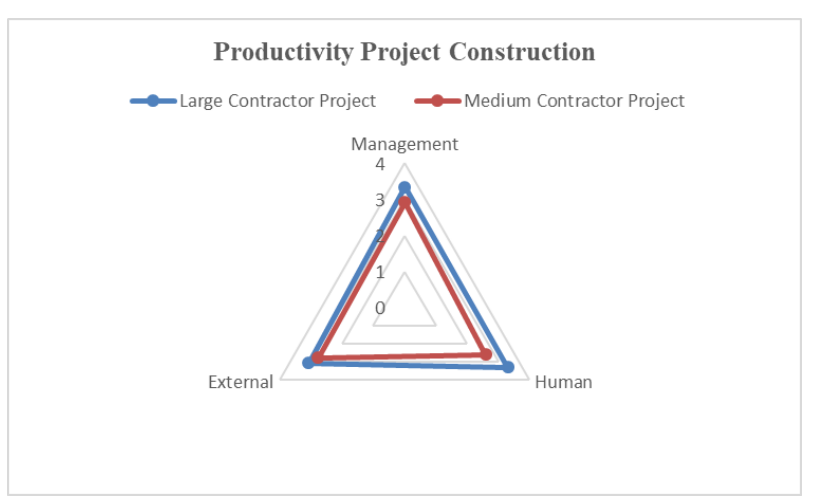

Figure 17. Spider web project of BUMN and Private time, cost and quality 


\section{Conclusion}

From the results of this study, the weighting for the assessment of CPP (Construction Project Productivity) on the project was $73.8 \%$ on the internal level and $26.2 \%$ on the external level. At the internal level there were two categories: management category for $39.38 \%$ and human category for $34.42 \%$. In the category of management, there were 10 variables with each weighting as follows: Tool Availability (5.79\%), Availability of Materials (5.67\%), Construction Technology (2.01\%), Constructability Design (3.19\%), Adequacy Planning \& Risk Management Process (3.39\%), Rework (1.38\%), Site Layout (2.83\%), Safety (5.28\%), Construction Project Management (6.3\%), Inspection Delays (3.54\%). In the Human category there were 5 variables with each weighting as follows: Leadership (10.57\%), Labor Operating System (6.26\%), Teamwork (5.47\%), Communication (7.09\%), and Worker Turnover \& Availability (5.03\%). While for the external level there were 4 categories with each weighting as follows: Change orders $(10.11 \%)$, Partnership Interaction (5.79\%), Weather (4.87\%), and Location (5.43\%).

This CPP assessment model after being applied to several construction projects could result in a Productivity Project Management (CPP) productivity score so that the productivity level of a construction project could be identified. CPP Score could be an assessment to illustrate how high the productivity level of a construction project which could also be a reference by the perpetrator of a similar construction project so as to know the strengths and weaknesses of the project, as well as corrective action which could improve the productivity of the project. This CPP assessment model was useful for construction actors such as contractors and project owners (owners) or consultants.

The results show that the implementation model for the project undertaken by the BUMN contractor has an average productivity score of 4 out of 5 scales while private contractor has value of productivity scale of 3 out of 5 scales. Overall construction projects undertaken by BUMN and private contractors have scaled productivity values of 3 out of 5 scales.

\section{References}

1. K.M. El-Gohary, R.F. Aziz, Factors Influencing Construction Labor Productivity in Egypt, J. Manage. Eng., 30(1), 1-9 (2014).

2. R. Ratnayanti, Produktivitas Tenaga Kerja Konstruksi pada Setiap Jenjang Keahlian di Lapangan, Jurnal Teknik Sipil ITB, Bandung (2003).

3. H.S. Park, S.R. Thomas, R.L. Tucker, Benchmarking of Construction Productivity, J. Constr. Eng. Manage., 131(7), 772-778 (2005).

4. K.P. Grant, J.S. Pennypacker, Project Management Maturity : An Assesment of Project Management Capabilities Among and Between Selected Industries, IEEE Transaction on Engineering Management, 53 No.1, hal. 59-68 (2006).
5. A.A. Tsehayae, A.R. Fayek, Developing and Optimizing Context-Specific Fuzzy Inference System-Based Construction Labor Productivity Models, J. Constr. Eng. Manage., 142 (7), 04016017 (2016).

6. N. Brookes, M. Butler, P. Dey, R. Clark, The Use of Maturity Models in Improving Project Management Performance, International Journal of Managing Project in Business, 7 No.2, hal.231-246 (2014).

7. D. Hillson, Assesing Organisational Project Management Capability, Journal of Facilities Management, 2 No.3, hal.298-311 (2003).

8. S. Durdyev, S. Ismail, On-site construction productivity in Malaysian infrastructure projects, Structural Survey, 34 No. 4/5 (2016).

9. R. Hughes, D. Thorpe, A review of enabling factors in construction industry productivity in an Australian environment, Construction Innovation, 14 No. 2 (2014),

10. M. Zakeri, P.O. Olomolaiye, G.D. Holt, F.C. Harris, A survey of constraints on Iranian construction operatives' productivity, J. Constr. Manage. Econ., 14(5), 417-426 (1996).

11. M. Liberda, J. Rawanpura, G. Jergeas, Construction Productivity Improvement: A Study of Human, Management and External Issues, Construction Research Congress (2004).

12. J. Ravianto, Produktivitas dan Teknologi, Lembaga Sarana Informasi dan Produktivitas, Jakarta. 1985 (1985).

13. M. Sinungan, Produktivitas Apa dan Bagaimana, Jakarta, PT. Bumi Aksara (2000).

14. V. Gasper, Manajemen Produktivitas Total Strategi Peningkatan Produktivitas Bisnis Global, , Jakarta. PT. Gramedia Pustaka Utama (2000).

15. Asiyanto, Manajemen Produksi untuk Jasa Konstruksi, Jakarta, Pradnya Paramita (2005).

16. I.W. Ervianto, Manajemen Proyek Konstruksi, Edisi Revisi, Penerbit Andi, Yogyakarta (2005).

17. E.C. Lim, J. Alum, Construction productivity: Issues encountered by contractors in Singapore, Int. J. Proj. Manage., 13(1), 51-58 (1995).

18. D.W. Halligan, L.A. Demsetz, J.D. Brown, C.B. Pace, Action-response model and loss of productivity in construction, J. Constr. Eng. Manage., 120:1(47), 47-64 (1994).

19. J. Hansen, E. Mowen, Management Accounting, Southwestern College Publishing. Cincinnati, Ohio (1997)

20. P.F. Kaming, P.O. Olomolaiye, G.D. Holt, F.C. Harris, Factors influencing craftsmen's productivity in Indonesia, Int. J. Proj. Manage., 15(1), 21-30 (1997)

21. P. Soekirno, Pengantar Manajemen Proyek, Diktat Kuliah Magister Teknik Sipil UII, Yogyakarta (1999)

22. I. Dipohusodo, Manajemen Proyek dan Konstruksi, Kanisius, Yogyakarta (1996)

23. M. Liu, G. Ballard, W. Ibbs, Work flow variation and labor productivity: Case study, J. Manage. Eng., 236-242 (2011) 
24. G. Jargeas, Improving Construction Productivity on Alberta Oil and Gas Capital Projects, Alberta Finance and Enterprise, Canada (2009)

25. H. Maylor, Project Management, Edisi ke-4, Harlow: Pearson Education (2010)

26. I. Widiasanti, Lenggogeni, Manajemen Konstruksi, hal.25, Penerbit PT Remaja Rosdakarya, Bandung (2014)

27. Ng.S. Thomas, R.M. Skitmore, K.C. Lam, A.W.C. Poon, Demotivating factors influencing the productivity of civil engineering projects, Project Management, 139-146 (2004)

28. S. Mohammed, Benchmarking and improving construction productivity, Benchmarking for Quality Management \& Technology, 3 No. 3 pp. 50-58 (1996)

29. R.M.W. Horner, B.T. Talhouni, H.R. Thomas, Preliminary results of major labour productivity monitoring programme, Proc., $3^{\text {rd }}$ Yugoslavian Symp. on Construction Management, Zagreb Univ., Croatia, 18-28 (1989).

30. A. Enshassi, S. Mohamed, Z.A. Mustafa, P.E. Mayer, Factors Affecting Labor Productivity in Building Project in Gaza Strip, Journal of Civil Engineering and Management, 15(3) : 269-280. Vol. 13 No. 4, pp. 245-254 (2007)

31. H.M. Alinaitwe, J.A. Mwakali, B. Hansson, Factors affecting the productivity of building craftsmenStudies of Uganda, J. Civ. Eng. Manage., 13(3), 169-176 (2007)

32. A. Makulsawatudom, M. Emsley, K. Sinthawanarong, Critical factors influencing construction productivity in Thailand, J. King Mongkut's Univ. Technol., 14(3), 1-6 (2004)

33. K. Abdul, W.P. Lee, M.S. Jaafar, S.M. Sapuan, A.A.A. Ali, Factors affecting construction labour productivity for Malaysian residential projects, J. Struct. Surv., 23(1), 42-54 (2005)

34. A.M. Jarkas, C.G. Bitar, Factors Affecting Construction Labor Productivity in Kuwait, Journal of Construction Engineering Management, 20(10), 811 820. (2012)

35. P.F. Kaming, P.O Olomolaiye, G.D. Holt, F.C. Harris, Factors influencing craftsmen's productivity in Indonesia, Int. J. Proj. Manage., 15(1), 21-30 (1997)

36. J. Heizer, B. Render, Operations Management, Jakarta, Salemba Empat (2006) 